\title{
Clinical Assessment of Impacted Lower Third Molars at Ekpan, Delta State in Nigeria
}

\author{
Mabel Okiemute Etetafia ${ }^{1}$, Ese Anibor ${ }^{2}$, Martins Obaroefe ${ }^{2}$
}

${ }^{1}$ Department of Oral and Maxillofacial Surgery, Delta State University Teaching Hospital, Ogharha, Delta State, Nigeria.

${ }^{2}$ Department of Human Anatomy and Cell Biology, Faculty of Basic Medical Sciences, Delta State University, Abraka, Nigeria.

\section{ABSTRACT}

Introduction: Diagnosis and management of impacted mandibular third molars call for a cogent appraisal and treatment choice both for the sick person and the dental practitioner. This academic work scrutinized the pattern as well as treatment of impacted mandibular third molars at the Teem Clinic and Dental Centre, Ekpan, Delta State, in Nigeria.

Materials and Methods: This cross-sectional survey involved 131 cases who reported impacted mandibular third molars. The age, gender, impacted tooth, type of impaction, pathological conditions, and treatment proffered were recorded.

Results: The male to female ratio was $0.8: 1$, with an age range of 10 to 40 years. Of the lower third molar impactions $58(42.0 \%)$ were mesioangular, $5(3.6 \%)$ horizontal, $18(13.0 \%)$ vertical and 57 $(41.3 \%)$ were distoangular. A total of 47 (34.1\%) quested for dental attention following varying degrees of pain induced by pericoronitis. Teeth removal was accomplished for $76(55.0 \%)$ owing to carious lesions on the impacted teeth, proximate tooth, or both. Surgical extraction was the option taken in $69(50.0 \%)$ with caries on the impacted teeth while $3(2.2 \%)$ had to pull out of their teeth done owing to carious lesions on the bordering second molars. In $3(2.2 \%)$ both the impacted third molar and the proximate second molar were decayed.

Conclusions: The prevailing indication for pulling out impacted mandibular third molars was acute pericoronitis. Mesioangular sort of impaction was most recurrent and ought to be considered for the plausibility of frequentness of complications.

Keywords: Impacted Lower; pericoronitis; Third Molars;

\section{Correspondence:}

Dr. Ese Anibor, Ph.D.

Senior Lecturer, Department of Human Anatomy and Cell Biology

Faculty of Basic Medical Sciences, Delta State University, Abraka, Nigeria

ORCID ID: 0000-0003-1066-8402

Email: eseovo2000@yahoo.com

Submitted: $16^{\text {th }}$ June 2020

Accepted: $16^{\text {th }}$ November 2020

Source of Support: None

Conflict of Interest: None

Citation: Etetafia MO, MH, Anibor E, SI, Obaroefe M. Clinical Assessment of Impacted Lower Third Molars at Ekpan, Delta State in Nigeria. NMJ 2020;3(2):3525. DOI $10.3126 / \mathrm{nmj} . \mathrm{v} 3 \mathrm{i} 2.29486$

\section{INTRODUCTION}

Expository critique of relevant texts divulged that inferior third molars are constantly impacted teeth and surgical extraction has come to be a prevailing dentoalveolar procedure. Impacted inferior third molars are oftentimes relatable with operculitis, periodontal disease, neoplasm, cystic lesions, and deleterious outcomes on proximate teeth. ${ }^{1}$
Sufferers with impacted inferior third molars can manifest with pain, caries, gingivitis as well as other oral infections. ${ }^{2}$ Swots submitted that third molars are involved in crowding and in extreme situations, riddance of the impacted molars may be endorsed. ${ }^{3}$ To alleviate relatable symptoms, such teeth are chosen to go through conservative or surgical extraction. ${ }^{4}$ 
Even though impacted lower third molars stay asymptomatic for years, surgical extractions are performed to boycott lesions. Dental Surgeons see prophylactic elimination of such teeth as the paragon option. ${ }^{5}$ Factors correlated with the manifestation of complications include dotage, sex, health, smoking, the magnitude of impaction, surgical expertise, and the surgical procedure employed. ${ }^{6,7}$

In Nigeria, inquisitions on impacted lower third molars were carried out by academicians from the southwest axis and northwestern regions with diminutive groundwork from the southerly geopolitical area. ${ }^{8-13}$ This explicates the rationale behind this inquiry. This academic work scrutinized the pattern as well as treatment of impacted mandibular third molars at the Teem Clinic and Dental Centre, Ekpan, Delta State, in Nigeria.

\section{MATERIALS AND METHODS}

This cross-sectional study considered 138 impacted mandibular third molar teeth seen at the Teem Clinic and Dental Centre in Ekpan, Delta State, Nigeria. Specifics on 131 valetudinarians (57 males and 74 females) tended for maladies related to impacted mandibular third molars were put down. The details were compiled from the dossiers of the sufferers with impacted mandibular third molar teeth seen from $1^{\text {st }}$ January 2003 to $31^{\text {st }}$ December 2012.

The age, gender, impacted tooth, type of impaction, pathological conditions, and treatment proffered were recorded. Associated pathologies assessed according to the sort of impaction were also noted. The data was tabulated and displayed by periodicity and allotment using SPSS version 20. Chi-square was used to ascertain the association between the categorical variables investigated.

\section{RESULTS}

A total of 131 patients made up of 57 (43.5\%) males and $74(56.5 \%)$ females (male to female ratio was $0.8: 1$ ) were investigated. The age range of the attendees was 10 to 40 years with the majority in the age group of $21-30$ years $(n=85 ; 64.5 \%)$ followed by $31-40$ years $(n=28 ; 21.7 \%)$ and $0-20$ years $(n=18 ; 13.7 \%)$. The 21 to 25 years age class was overwhelmed with impactions $(42.8 \%)$ as disclosed in Table 1. Mesioangular impaction was predominant though without inter-correlation to peer groups $(\mathrm{p}>0.05)$ except in the 21-25 years age bracket $(\mathrm{p}=0.016)$ as divulged in Table 1 .

Table 1: Placement of pattern of impaction between various age classes

\begin{tabular}{|c|c|c|c|c|c|c|c|c|c|}
\hline Age (years) & Angulation & Total & Chi-square & P-value & Age (years) & Angulation & Total & Chi-square & P-value \\
\hline \multirow[t]{5}{*}{$10-15$} & Mesioangular & $1(50.0 \%)$ & & & $26-30$ & Mesioangular & $17(51.5 \%)$ & & \\
\hline & Horizontal & - & & & & Horizontal & $1(3.0 \%)$ & & \\
\hline & Vertical & - & 2.000 & 0.157 & & $\begin{array}{l}\text { Vertical } \\
\text { impacted }\end{array}$ & $2(6.1 \%)$ & 11.026 & 0.946 \\
\hline & Distoangular & $1(50.0 \%)$ & & & & Distoangular & $13(39.4 \%)$ & & \\
\hline & Total & $2(100.0 \%)$ & & & & Total & $33(100.0 \%)$ & & \\
\hline \multirow[t]{5}{*}{$16-20$} & Mesioangular & $6(35.3 \%)$ & & & 31-35 & Mesioangular & $6(42.9 \%)$ & & \\
\hline & Horizontal & - & & & & Horizontal & - & & \\
\hline & Vertical & $3(17.6 \%)$ & 8.500 & 0.386 & & Vertical & $2(14.3 \%)$ & 11.083 & 0.197 \\
\hline & Distoangular & $8(47.0 \%)$ & & & & Distoangular & $6(43.1 \%)$ & & \\
\hline & Total & $17(100.0 \%)$ & & & & Total & $14(100.0 \%)$ & & \\
\hline \multirow[t]{5}{*}{$21-25$} & Mesioangular & $21(37.5 \%)$ & & & $36-40$ & Mesioangular & $7(43.8 \%)$ & & \\
\hline & Horizontal & $3(5.4 \%)$ & & & & Horizontal & $1(6.3 \%)$ & & \\
\hline & Vertical & $9(16.1 \%)$ & 33.240 & 0.016 & & Vertical & $2(12.5 \%)$ & 9.992 & 0.266 \\
\hline & Distoangular & $23(50.1 \%)$ & & & & Distoangular & $6(37.6 \%)$ & & \\
\hline & Total & $56(100.0 \%)$ & & & & Total & $16(100.0 \%)$ & & \\
\hline
\end{tabular}

Regarding the angulations of the third molar impactions, 58 (42.0\%) were mesioangular, $5(3.6 \%)$ horizontal, $18(13.0 \%)$ vertical and 57 $(41.3 \%)$ belong to the distoangular category. It was revealed that $47(34.1 \%)$ sought dental care on grounds of pain provoked by acute pericoronitis (Table 2). Acute pericoronitis was a recurrent reason for tooth removal as seen with 38.9\% of the individuals (Table 3).

Table 2: Patterns of impaction of the third molar and complications among the study population

\begin{tabular}{|c|c|c|c|c|c|c|c|}
\hline \multirow[b]{2}{*}{ Pattern } & \multicolumn{7}{|c|}{ Complication } \\
\hline & $\begin{array}{l}\text { Acute } \\
\text { pericoronitis }\end{array}$ & $\begin{array}{l}\text { Acute on chronic } \\
\text { pericoronitis }\end{array}$ & Chronic pericoronitis & Periodontal pocket & Dental caries & None & Frequency \\
\hline Mesioangular & 15 & 4 & 4 & 1 & 32 & 2 & 58 \\
\hline Horizontal & 2 & - & - & - & 3 & - & 5 \\
\hline Vertical & 5 & 1 & 1 & & 10 & 1 & 18 \\
\hline Distoangular & 16 & 4 & 4 & & 31 & 2 & 57 \\
\hline Total & 38 & 9 & 9 & 1 & 76 & 5 & 138 \\
\hline
\end{tabular}


Table 3: The disposition of the treatment rendered

\begin{tabular}{|c|c|c|c|c|c|c|}
\hline Complication & Leave alone & $\begin{array}{l}\text { Excision of } \\
\text { operculum }\end{array}$ & $\begin{array}{l}\text { Surgical extraction } \\
\text { of 3rd molar }\end{array}$ & $\begin{array}{l}\text { Extraction of } 2^{\text {nd }} \boldsymbol{\&} \\
3^{\text {rd }} \text { molars }\end{array}$ & $\begin{array}{l}\text { Incision and } \\
\text { Drainage }\end{array}$ & Total \\
\hline None & $1(0.7 \%)$ & $1(0.7 \%)$ & $3(2.2 \%)$ & - & - & $5(3.6 \%)$ \\
\hline Dental caries & $18(13.0 \%)$ & $10(7.2 \%)$ & $46(35.9 \%)$ & $1(0.7 \%)$ & $1(0.7 \%)$ & $76(55.0 \%)$ \\
\hline Acute pericoronitis & $5(3.6 \%)$ & $16(11.6 \%)$ & $15(10.9 \%)$ & $2(1.4 \%)$ & - & $38(27.5 \%)$ \\
\hline Chronic pericoronitis & - & $7(5.1 \%)$ & $1(0.7 \%)$ & - & $1(0.7 \%)$ & $9(6.5 \%)$ \\
\hline Acute on chronic pericoronitis & $1(0.7 \%)$ & $4(2.9 \%)$ & $4(2.9 \%)$ & - & & $9(6.5 \%)$ \\
\hline $\begin{array}{l}\text { Lower 3rd molar periodontal } \\
\text { pocket }\end{array}$ & - & $1(0.7 \%)$ & - & - & - & $1(0.7 \%)$ \\
\hline Total & $25(18.1 \%)$ & $39(28.3 \%)$ & $69(50.0 \%)$ & $3(2.2 \%)$ & $2(1.4 \%)$ & $138(100.0 \%)$ \\
\hline
\end{tabular}

Extractions were performed for 76 (55.0\%) individuals ascribable to carious lesions on the impacted teeth, proximate tooth, or both (Table 3). Surgical extractions were accomplished in $69(50.0 \%)$ sufferers with caries on the impacted teeth while $3(2.2 \%)$ had extraction ascribed to caries on the nearby second molar (Table $3)$. In $3(2.2 \%)$ both the impacted tooth and the adjacent second molar were carious. Most extractions were done in the 21 to 30 years old group $(n=47 ; 35.8 \%)$, followed by 31 to 40 years $(n=15$; $11.4 \%)$.

A total of 138 impacted lower third molars were considered and mesioangular impaction was surmised to be correlative with various numbers of complications $(\mathrm{p}>0.05)$ (Table 2). More lesions and therapeutic interventions occurred in the 21 to 25 years age bracket $(\mathrm{p}<0.05)$.

\section{DISCUSSION}

The current scrutiny divulged that females $(57.0 \%)$ were affected by impacted third lower molars more often than the males (43.0\%). This is in accord with inquiries done previously. ${ }^{6,14}$ Certain inquirers saw that impaction of the mandibular third molar prevailed similarly in the two genders. ${ }^{9,13}$ The 21 to 25 years peer-group suffered the most $(42.8 \%)$ in this inquisition. A prior scrutinization established that the 21 to 30 years compeers are those overwhelmed with impacted inferior third molars. ${ }^{14}$

In this review, mesioangular angulation is the most noticeable pattern noted for the mandibular third molars. Analyses on orientations of impacted mandibular third molars expressed that mesioangular kind of impaction was the most incessantly viewed. ${ }^{4,14,15}$ This inquiry revealed that mesioangular inclination is the most noticeable angulation though not with an explicit tiein to the age classes $(p>0.05)$. This outcome acceded to that from foregoing inquiries. ${ }^{6,14}$ Other Inquirers saw vertical impactions as the most frequent impaction kind in their inquisitions. ${ }^{5,7}$ Mesioangular impaction was identified to be correlated with the pinnacle of damages $(p<0.05)$. This is in complete accord with data from a different perusal. ${ }^{14}$

Plenitude of 47 (34.1\%) sufferers quested for oral care on account of pain triggered by pericoronitis. This affirmed the deductions of other inquirers. ${ }^{1,2,4}$ Acute pericoronitis is a recurring indication for taking out impacted inferior third molars in this disquisition. This was in accordance with reports from other acquisitions. ${ }^{4,8,12}$ However, caries and crowding are unfavorable sequelae that overwhelmed others concerning impacted inferior third molars. ${ }^{2,3}$

Extraction of teeth was performed for $72(52.2 \%)$ of the participators owing to carious lesions. This is in conformity with the course of treatment specified by other inquisitors. ${ }^{1,3,4}$

This acquisition's key strength was the one-on-one intra-oral examination of patients allowing the clinician to acquire details. The main limitation of this inquisition was the failure to obtain a $100 \%$ true and sincere response from the patients during history taking.

\section{CONCLUSIONS}

The prevailing indication for pulling out impacted mandibular third molars was acute pericoronitis. Mesioangular sort of impaction was most recurrent and ought to be considered for the plausibility of frequentness of complications.

\section{REFERENCES}

1. Mercier P, Precious D. Risks and benefits of removal of impacted third molars. A critical review of the literature. Int J Oral Maxillofac Surg. 1992; 21:17-27. Crossref

2. Fuselier JC, Ellis EE, Dabson TB. Do Mandibular Third Molars Alter the Risk of Angle Fracture? J. Oral Maxillofac. Surg. 2002; 60: 514-8. Crossref

3. Woldenberg Y, Gatot I, Bodner L. Iatrogenic mandibular fracture associated with third molar removal. Can it be prevented? Med Oral Patol Oral Cir Bucal. 2007;12:E70-2. Website
4. Vani PP, Fazil AN, Ramprasad M, Narendra VP, Syed A, Sandeep. Correlating the clinical assessment of impacted mandibular third molars with panoramic radiograph and intraoral periapical radiograph. J Int Soc Prev Community Dent. 2016; 6(3):S219-S225. Crossref

5. Stanley HR, Alattar M, Collett WK, Stringfellow HR Jr, Spiegel EH. Pathological sequelae of "neglected" impacted third molars. J Oral Pathol 1988;17:113-7. Crossref

6. Sisk AL, Hammer WB, Shelton DW, Joy ED Jr. Complications following removal of impacted third molars: the role of the experience of the surgeon. J Oral Maxillofac Surg. 1986; 44:855-9. Crossref 
7. Benediktsdottir IE, Wenzel A, Petersen JK, Hintze H. Mandibular third molar removal: Risk indicators for extended operation time, postoperative pain, and complications. Oral Surg Oral Med Oral Pathol Oral Radiol Endod. 2004; 79:434-46. Crossref

8. Otasowie DO, Godwin OB. Pattern of impacted mandibular third molars in Calabar, Nigeria. Afri J of Med and Health Sci. 201615 (1): 14-17. Crossref

9. Bamgbose BO, Akinwande JA, Adeyemo WL, Ladeinde AL, Arotiba GT, Ogunlewe MO. Effects of co-administered dexamethasone and diclofenac potassium on pain, swelling and trismus following third molar surgery. Head Face Med. 2005; 1:11. Crossref

10. Osunde OD, Saheeb BD, Adebola RA. Comparative study of the effect of single and multiple suture techniques on inflammatory complications following third molar surgery. J Oral Maxillofac Surg. 2011; 69:971-6. Crossref

11. Osunde OD, Adebola RA, Saheeb BD. A comparative study of the effect of suture-less and multiple suture techniques on inflammatory following third molar surgery. Int J Oral Maxillofac Surg. 2012; 41:1275-9. Crossref
12. Saheeb BD, Obuekwe ON. An audit of mandibular third molar surgery. Niger J Surg Res. 2001; 3:66-74. Crossref

13. Osunde OD, Bassey GO. Pattern of impacted mandibular third molars in Calabar, Nigeria. Afr J Med Health Sci. 2016;15:14-7. Crossref

14. Kumar VR, Yadav P, Kahsu E, Girkar F, Chakraborty R. Prevalence and Pattern of Mandibular Third Molar Impaction in Eritrean Population: A Retrospective Study. J Contemp Dent Pract. 2017; 18(2):100-6. Crossref

15. Quek SL, Tay CK, Tay KH, Toh SL, Lim KC. Pattern of Third Molar Impaction in a Singapore Chinese Population: A Retrospective Radiographic Survey. Int. J. Oral Maxillofac. Surg. 2003; 32: 548-52. Crossref 